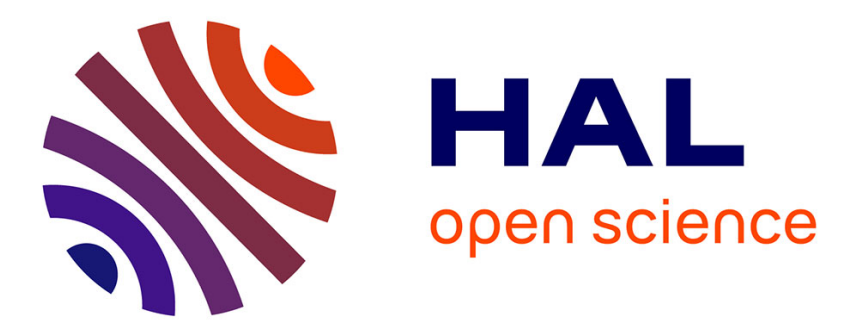

\title{
Substituent effects on the photophysical properties of 2,9-substituted phenanthroline copper(I) complexes: a theoretical investigation
}

\author{
Christophe Gourlaouen, Keiko Takano, Ai Hamano, Chantal Daniel
}

\section{To cite this version:}

Christophe Gourlaouen, Keiko Takano, Ai Hamano, Chantal Daniel. Substituent effects on the photophysical properties of 2,9-substituted phenanthroline copper(I) complexes: a theoretical investigation. ChemPhysChem, 2021, 22, pp.509-515. 10.1002/cphc.202000868 . hal-03034539

\author{
HAL Id: hal-03034539 \\ https://hal.science/hal-03034539
}

Submitted on 2 Dec 2020

HAL is a multi-disciplinary open access archive for the deposit and dissemination of scientific research documents, whether they are published or not. The documents may come from teaching and research institutions in France or abroad, or from public or private research centers.
L'archive ouverte pluridisciplinaire HAL, est destinée au dépôt et à la diffusion de documents scientifiques de niveau recherche, publiés ou non, émanant des établissements d'enseignement et de recherche français ou étrangers, des laboratoires publics ou privés. 


\title{
Substituent effects on the photophysical properties of 2,9- substituted phenanthroline copper(I) complexes: a theoretical investigation
}

\author{
Christophe Gourlaouen, ${ }^{*[a]}$ Ai Hamano, ${ }^{[a, b]}$ Keiko Takano,${ }^{[b]}$ Chantal Daniel ${ }^{*[a]}$
}

This article is dedicated to the scientific career of our colleague Dr Olivier Poizat, CNRS researcher, for his outstanding contribution to excited-state relaxation dynamics

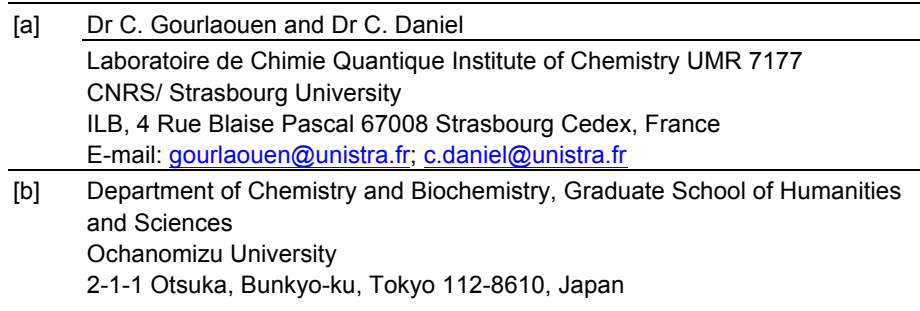

Supporting information for this article is given via a link at the end of the document.

\begin{abstract}
The electronic and nuclear structures of a series of $\left[\mathrm{Cu}\left(2,9-(\mathrm{X})_{2} \text {-phen }\right)_{2}\right]^{+} \quad$ copper $(\mathrm{I}) \quad$ complexes (phen $=1,10-$ phenanthroline; $\mathrm{X}=\mathrm{H}, \mathrm{F}, \mathrm{Cl}, \mathrm{Br}, \mathrm{I}, \mathrm{Me}, \mathrm{CN}$ ) in their ground and excited states is investigated by means of density functional theory (DFT) and time-dependent (TD-DFT) methods. Subsequent BornOppenheimer molecular dynamics is used for exploring the $T_{1}$ potential energy surface (PES). The $T_{1}$ and $S_{1}$ energy profiles, which connect the degenerate minima induced by ligand flattening and $\mathrm{Cu}$ $\mathrm{N}$ bond symmetry breaking when exciting the molecule are calculated as well as transition state (TS) structures and related energy barriers. Three nuclear motions drive the photophysics, namely the coordination sphere asymmetric breathing, the welldocumented pseudo Jahn-Teller (PJT) distortion and the bending of the phen ligands. This theoretical study reveals the limit of the static picture based on potential energy surfaces minima and transition states for interpreting the luminescent and TADF properties of this class of molecules. Whereas minor asymmetric $\mathrm{Cu}-\mathrm{N}$ bonds breathing accompanies the metal-to-ligand-charge-transfer relocalization over one or the other phen ligand, the three nuclear movements participate to the flattening of the electronically excited complexes. This leads to negligible energy barriers whatever the ligand $X$ for the first process and significant ligand dependent energy barriers for the formation of the flattened conformers. BornOppenheimer (BO) dynamics simulation of the structural evolution on the $T_{1}$ PES over 11 ps at $300 \mathrm{~K}$ confirms the fast backwards and forwards motion of the phenanthroline within 200-300 fs period and corroborates the presence of metastable $\mathrm{C}_{2}$ structures.
\end{abstract}

\section{Introduction}

Copper(I) complexes with chelating diimine ligands challenge $\left[\mathrm{Ru}(\mathrm{bpy})_{3}\right]^{2+}$ complexes in terms of absorption wavelength, photoluminescence and redox properties ${ }^{[1]}$ decades of synthetic breakthrough for the improvement of luminescence quantum yields and emission lifetimes of $\mathrm{Cu}(\mathrm{I})$-bis(phenanthroline) complexes it appeared that steric hindrance around the chelating nitrogen atoms of the diimine ligands significantly affects the photophysics of this class of molecules. ${ }^{[2]}$ The presence of alkyl chains or aromatic groups at the 2 an 9 positions of the phenanthrolines clearly impacts the luminescence properties. ${ }^{[1 \mathrm{a}, \mathrm{b}, \mathrm{c},[2 \mathrm{2a}],[3]}$ Replacing the methyl groups of $\left[\mathrm{Cu}(\mathrm{dmp})_{2}\right]^{+}(\mathrm{dmp}=$ 2,9-dimethyl-1,10-phenanthroline) by bulky substituents may increase the quantum yields by two orders of magnitude and the emission lifetimes from a few nanoseconds (ns) to a few microseconds ( $\mu \mathrm{s})$. Whereas the steric effects are largely documented, the electronic influence of the substituents on the photophysics is less known. In particular, electron withdrawing vs. electron donating ligands while preserving the same steric constraints in the excited states may alter NIR luminescence properties in less crowded $\mathrm{Cu}(\mathrm{I})$ complexes as exemplified for the recently synthesized series $\left[\mathrm{Cu}\left(2,9-(\mathrm{X})_{2} \text {-phen }\right)_{2}\right]^{+}(\mathrm{X}=\mathrm{Cl}, \mathrm{Br}, \mathrm{I})$ as compared to $\left[\mathrm{Cu}(\mathrm{dmp})_{2}\right]^{+} .^{[4]}$ Ultrafast transient absorption and temperature dependent steady-state fluorescence spectroscopies combined with computational chemistry pointed to very similar behavior of the three complexes as far as $S_{n} \rightarrow S_{1}$ sub-ps decay, absorption, and redox properties are concerned. All three complexes are luminescent at room temperature indicating that the $X$ substituents are bulky enough for preventing interactions with solvent molecules or between excited state species. However photoluminescence efficiency as well as its dependence on the temperature is strongly determined by the nature of $X$ with a thermally activated delay fluorescence TADF behavior for $X=C l$, $\mathrm{Br}$ and an anti-TADF behavior for $\mathrm{X}=\mathrm{I}$ for which an increase of emission quantum yield is observed when decreasing the temperature. The singlet-triplet energy gap $\Delta \mathrm{E}_{\mathrm{S} 1 \mathrm{~T} 1}$, spin-orbit coupling (SOC) together with the computed potential energy profiles that connect the $S_{1}$ and $T_{1}$ excited state structures starting from the initial $D_{2 \mathrm{~d}}$ tetrahedral conformation at FranckCondon to the quasi-square planar configuration $D_{2}$ promoted by pseudo-Jahn-Teller (PJT) distortion and to further symmetry reduced $\mathrm{C}_{2}$ structures associated to $\mathrm{Cu}-\mathrm{N}$ breathing and electronic re-localization give some clue about the mechanism behind the observed photophysics. ${ }^{[4]}$ Nevertheless, in order to improve our understanding it is required to determine the transition states (TS) that connect the different conformers and 
to compute the Gibbs free energy profiles. This is the purpose of the present study that extends our previous investigation from the halogen substituted complexes to $\left[\mathrm{Cu}(\text { phen })_{2}\right]^{+},\left[\mathrm{Cu}(\mathrm{dmp})_{2}\right]^{+}$ and $\left[\mathrm{Cu}\left(2,9-(\mathrm{CN})_{2} \text {-phen }\right)_{2}\right]^{+}$for comparison and does not consider early time (sub-ps) dynamical effects investigated both experimentally ${ }^{[5]}$ and theoretically. ${ }^{[6]}$

\section{Results and Discussion}

Structures and potential energy profiles. The general structure of $\left[\mathrm{Cu}\left(2,9-(\mathrm{X})_{2} \text {-phen }\right)_{2}\right]^{+}$in the $\mathrm{S}_{0}$ closed shell electronic ground state of $D_{2 d}$ symmetry is depicted in Scheme 1 where $C \alpha$ is the carbon atom used as reference for the definition of important geometrical parameters and A, B are the center of the phenyl rings.

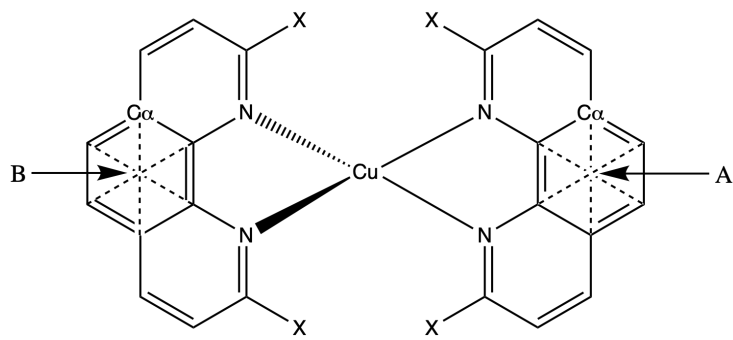

Scheme 1. General structure of $\left[\mathrm{Cu}\left(2,9-(\mathrm{X})_{2}-\text { phen }\right)_{2}\right]^{+}$in the $\mathrm{S}_{0}$ electronic ground state. $C \alpha$ is the carbon atom used as reference for the definition of important geometrical parameters and A, B are the centre of the phenyl rings.

The four Cu-N bonds lengths are identical varying from $2.07 \AA$ $(\mathrm{X}=\mathrm{Me})$ to $2.08 \AA(\mathrm{X}=\mathrm{H})$ (Table S1, SI section) with the A-Cu$B$ bond and $\mathrm{C} \alpha-\mathrm{A}-\mathrm{B}-\mathrm{C} \alpha$ tetrahedral angles of $180^{\circ}$ and $90^{\circ}$, respectively. In the absence of external perturbation (solvent, excimers), of asymmetric ligands or ligands interactions this highly symmetric structure is conserved with two degenerate HOMO and two degenerate LUMO orbitals (Scheme 2). The LUMO of e symmetry are followed by two orbitals of a2 and b1 symmetry. A noticeable exception is the cyano complex for which the orbital order of the two sets of LUMO is reversed, a2 and b1 orbital becoming now the LUMOs (Scheme S1, SI section) due to the significant electronic contribution of the cyano groups. In the other $\left[\mathrm{Cu}\left(2,9-(\mathrm{X})_{2}-\text { phen }\right)_{2}\right]^{+}$complexes the electronic contribution of the $\mathrm{X}$ groups to these orbitals is very small.
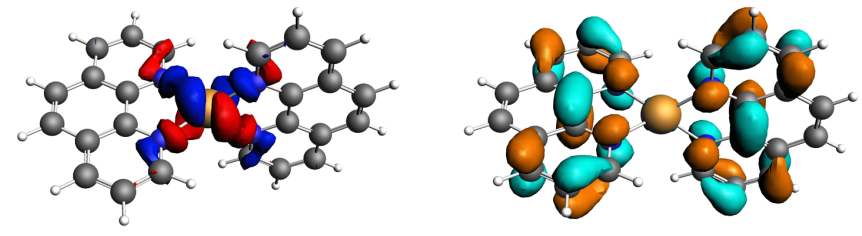

Scheme 2. HOMO (left) and LUMO (right) of $\left[\mathrm{Cu}\left(2,9-(\mathrm{X})_{2}-\text { phen }\right)_{2}\right]^{+}(X \neq \mathrm{CN})$ in the $\mathrm{S}_{0}$ electronic ground state.
The potential energy surfaces (PES) associated to metal-toligand-charge-transfer (MLCT) $\mathrm{S}_{1}$ and $\mathrm{T}_{1}$ excited states are characterized by several minima generated by symmetry breaking. Indeed, the partial depopulation of $\mathrm{d}_{\mathrm{Cu}}$ orbitals correlates with the flattening (Scheme 3), namely a decrease of $\mathrm{C} \alpha-\mathrm{A}-\mathrm{B}-\mathrm{C} \alpha$ and a lowering of symmetry to $\mathrm{D}_{2}$ that generates two minima in all complexes. This nuclear relaxation may be supplemented by an electronic re-localization on one or the other phenanthroline (Scheme 3 ) accompanied by $\mathrm{Cu}-\mathrm{N}$ bond breathing leading to $\mathrm{C}_{2}$ symmetry breaking generating two minima in most complexes, except in the hydride and cyano substituted ones. Consequently, the halide and methyl substituted complexes in their $S_{1}$ and $T_{1}$ excited states PES are characterized by four degenerate minima whereas the PES of the hydride and cyano substituted molecules possess two mimina. The $\mathrm{C}_{2}$ minima can be paired following exciton localization (scheme 3 bottom) in the same flattening orientation. These pairs are connected by $\mathrm{TS}_{\mathrm{A}}$ (Figure 1) in which the exciton is delocalized over the two ligands while the complex remains flat. $T S_{A}$ is of higher $D_{2}$ point group and is associated to the $\mathrm{Cu}-\mathrm{N}$ bond breathing. The minima can also be paired by different flattening orientation (scheme 3 , top), the exciton remaining localized on the same ligand. These pairs are connected by $\mathrm{TS}_{\mathrm{B}}$, which is associated to the $\mathrm{A}-\mathrm{Cu}-\mathrm{B}$ angle bending combined with the torsion along the $\mathrm{C} \alpha-\mathrm{A}-\mathrm{B}-\mathrm{C} \alpha$ dihedral angle.

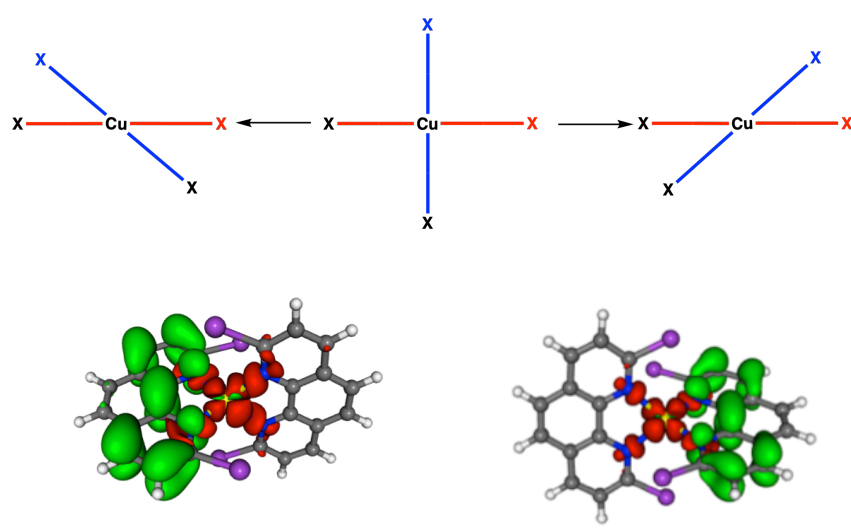

Scheme 3. (top) Flattening of $\left[\mathrm{Cu}\left(2,9-(\mathrm{X})_{2}-\text { phen }\right)_{2}\right]^{+}$(side view). The centre structure corresponds to the $S_{0}$ electronic ground state. The $S_{1}$ and $T_{1}$ excited states can adopt either the left or the right structures. (bottom) Electron density differences between the $S_{0}$ electronic ground states and the lowest $S_{1} / T_{1}$ excited states associated to the flattened degenerate structures (in red: reduction, in green: augmentation).

The three relevant geometrical parameters of $\left[\mathrm{Cu}\left(2,9-(\mathrm{X})_{2^{-}}\right.\right.$ phen $\left.)_{2}\right]^{+}, \mathrm{Cu}-\mathrm{N}, \mathrm{A}-\mathrm{Cu}-\mathrm{B}$ and $\mathrm{C} \alpha-\mathrm{A}-\mathrm{B}-\mathrm{C} \alpha$ optimized for the $\mathrm{T}_{1}$ PES minima and TS structures that connect them are reported in Table 1 whereas the values associated to the $S_{1}$ PES can be found in Table $\mathrm{S} 1$ (SI section). The structure and energy determinations in $T_{1}$ have been performed both with Gaussian [16] $(\triangle S C F)$ and $A D F^{[17]}$ (TD-DFT), whereas the $S_{1}$ singlet structures were determined with ADF at the TD-DFT level starting form the frequency checked structures in $T_{1}$. Both methods give similar geometrical characteristics for $\mathrm{T}_{1}$ (Table $\mathrm{S} 1$, 
SI section). The $\mathrm{C} \alpha-\mathrm{A}-\mathrm{B}-\mathrm{C} \alpha$ dihedral angle measuring the flattening is evaluated below $50^{\circ}$ in the hydride and fluoride substituted complexes, with increasing values following the steric influence calculated at $65.1^{\circ}$ and $68.9^{\circ}$ at the $T_{1}$ and $S_{1}$ state minima, respectively of $\left[\mathrm{Cu}(\mathrm{dmp})_{2}\right]^{+}$. These values agree with the crystallographic data currently reported for this molecule $\left(68^{\circ}-88^{\circ}\right)^{[7]}$ as well as with theoretical results reported for $S_{1}(\sim$ $\left.70^{\circ}\right) \cdot{ }^{[6 \mathrm{~b}, 6 \mathrm{c}]}$

Table 1. Relevant geometrical parameters of $\left[\mathrm{Cu}\left(2,9-(\mathrm{X})_{2}-\text { phen }\right)_{2}\right]^{+} \mathrm{Cu}-\mathrm{N}$ (in $\AA$ ), A-Cu-B and $\mathrm{C} \alpha-\mathrm{A}-\mathrm{B}-\mathrm{C} \alpha\left(\right.$ in ${ }^{\circ}$ ) optimized for the $\mathrm{T}_{1}$ PES minima $\left(\mathrm{C}_{2}\right)$ and TS structures, $T S_{A}\left(D_{2}\right)$ and $T S_{B}\left(C_{s}\right)$, that connect them computed with Gaussian [Ref. 16].

\begin{tabular}{|c|c|c|c|c|c|c|c|c|c|}
\hline \multirow[t]{2}{*}{$x^{a}$} & \multicolumn{3}{|c|}{ Cu-N } & \multicolumn{3}{|c|}{ A-Cu-B } & \multicolumn{3}{|c|}{$\mathrm{C} \alpha-\mathrm{A}-\mathrm{B}-\mathrm{C} \alpha$} \\
\hline & $\min$ & $\mathrm{TS}_{\mathrm{A}}$ & $\mathrm{TS}_{\mathrm{B}}$ & $\min$ & $\mathrm{TS}_{\mathrm{A}}$ & $\mathrm{TS}_{\mathrm{B}}$ & $\min$ & $\mathrm{TS}_{\mathrm{A}}$ & $\mathrm{TS}_{\mathrm{B}}$ \\
\hline \multirow[t]{4}{*}{$\mathrm{H}$} & & 1.99 & 1.94 & & 180.0 & 161.1 & & 41.5 & 90.0 \\
\hline & & 1.99 & 1.94 & & & & & & \\
\hline & & 1.99 & 2.12 & & & & & & \\
\hline & & 1.99 & 2.12 & & & & & & \\
\hline \multirow[t]{4}{*}{$\mathrm{F}$} & 1.98 & 2.00 & 1.94 & 180.0 & 180.0 & 160.2 & 48.4 & 48.0 & 90.0 \\
\hline & 1.98 & 2.00 & 1.95 & & & & & & \\
\hline & 2.02 & 2.00 & 2.12 & & & & & & \\
\hline & 2.02 & 2.00 & 2.12 & & & & & & \\
\hline \multirow[t]{4}{*}{$\mathrm{Cl}$} & 1.97 & 2.00 & 1.94 & 180.0 & 180.0 & 163.2 & 61.3 & 60.5 & 90.0 \\
\hline & 1.97 & 2.00 & 1.95 & & & & & & \\
\hline & 2.04 & 2.00 & 2.12 & & & & & & \\
\hline & 2.04 & 2.00 & 2.12 & & & & & & \\
\hline \multirow[t]{4}{*}{$\mathrm{Br}$} & 1.97 & 2.00 & 1.93 & 180.0 & 180.0 & 165.5 & 64.4 & 64.1 & 90.0 \\
\hline & 1.97 & 2.00 & 1.95 & & & & & & \\
\hline & 2.04 & 2.00 & 2.12 & & & & & & \\
\hline & 2.04 & 2.00 & 2.12 & & & & & & \\
\hline \multirow[t]{4}{*}{ I } & 1.97 & 1.99 & 1.92 & 180.0 & 177.9 & 169.4 & 68.6 & 69.2 & 90.0 \\
\hline & 1.97 & 2.01 & 1.96 & & & & & & \\
\hline & 2.05 & 1.99 & 2.12 & & & & & & \\
\hline & 2.05 & 2.01 & 2.12 & & & & & & \\
\hline \multirow[t]{4}{*}{$\mathrm{Me}$} & 1.97 & 1.99 & 1.94 & 180.0 & 180.0 & 179.1 & 65.0 & 62.7 & 90.0 \\
\hline & 1.97 & 1.99 & 1.94 & & & & & & \\
\hline & 2.03 & 1.99 & 2.11 & & & & & & \\
\hline & 2.03 & 1.99 & 2.11 & & & & & & \\
\hline \multirow[t]{4}{*}{$\mathrm{CN}$} & & 2.00 & 1.92 & & 180.0 & 159.9 & & 56.6 & 90.0 \\
\hline & & 2.00 & 1.97 & & & & & & \\
\hline & & 2.00 & 2.12 & & & & & & \\
\hline & & 2.00 & 2.12 & & & & & & \\
\hline
\end{tabular}

${ }^{a}$ For $\mathrm{X}=\mathrm{H}$ and $\mathrm{CN} \mathrm{T}_{1}$ minimum keeps the $\mathrm{D}_{2}$ symmetry (real frequencies) and for $X=I$ the $T S_{A}$ structure keeps the $C_{2}$ symmetry the $D_{2}$ converged structure being a $2^{\text {nd }}$-order saddle point ( 2 imaginary frequencies).

The $\mathrm{TS}_{\mathrm{A}}$ transition state characterized by frequency analysis corresponds to the electronic de-localization upon excitation on one or the other phenanthroline and is of $D_{2}$ symmetry in all complexes, except for $\mathrm{X}=\mathrm{I}$ for which the structure converges to $\mathrm{C}_{2}$ by symmetry breaking due to A-Cu-B bending ( $177.8^{\circ}$ vs. $180.0^{\circ}$ ) (Table 1). The $\mathrm{TS}_{\mathrm{B}}$ transition state connects the two $\mathrm{C}_{2}$ flattened structures (Scheme 3 ). Its optimization leads to $C_{s}$ structures in all complexes characterized by a small A-Cu-B angle bending (high order saddle point with several imaginary frequencies) and a tetrahedral angle $\mathrm{C} \alpha-\mathrm{A}-\mathrm{B}-\mathrm{C} \alpha$ of $90.0^{\circ}$ (Table
1). The calculated $T_{1}$ transition state potential energy $(\Delta \mathrm{E})$ and Gibbs free energy $(\Delta G)$ differences are reported in Table 2 . The values calculated for the $S_{1}$ excited state are reported in Table S2 (SI section).

Table 2. Calculated transition state $T_{1}$ potential energy $(\Delta E)$ and Gibbs free energy $(\Delta \mathrm{G})$ differences in $\mathrm{kcal} \mathrm{mol}^{-1}$ computed with Gaussian [Ref. 16].

\begin{tabular}{lllll}
\hline & & $\mathrm{TS}_{\mathrm{A}}$ & \multicolumn{3}{c}{$\mathrm{TS}_{\mathrm{B}}$} \\
$\mathrm{X}$ & $\Delta \mathrm{E}$ & $\Delta \mathrm{G}$ & $\Delta \mathrm{E}$ & $\Delta \mathrm{G}$ \\
$\mathrm{H}$ & - & - & 13.4 & 12.6 \\
$\mathrm{~F}$ & 0.2 & -0.9 & 10.0 & 8.7 \\
$\mathrm{Cl}$ & 0.6 & -0.3 & 5.4 & 5.0 \\
$\mathrm{Br}$ & 1.0 & -0.2 & 4.3 & 3.7 \\
$\mathrm{I}$ & 1.0 & -0.7 & 2.4 & 1.3 \\
$\mathrm{Me}$ & 0.5 & -0.4 & 4.7 & 3.7 \\
$\mathrm{CN}$ & - & - & 8.6 & 7.3 \\
\hline
\end{tabular}

The general potential energy profiles associated to the $S_{1}$ and $T_{1}$ states and connecting $\mathrm{C}_{2}$ degenerate minima are depicted in Figure 1.

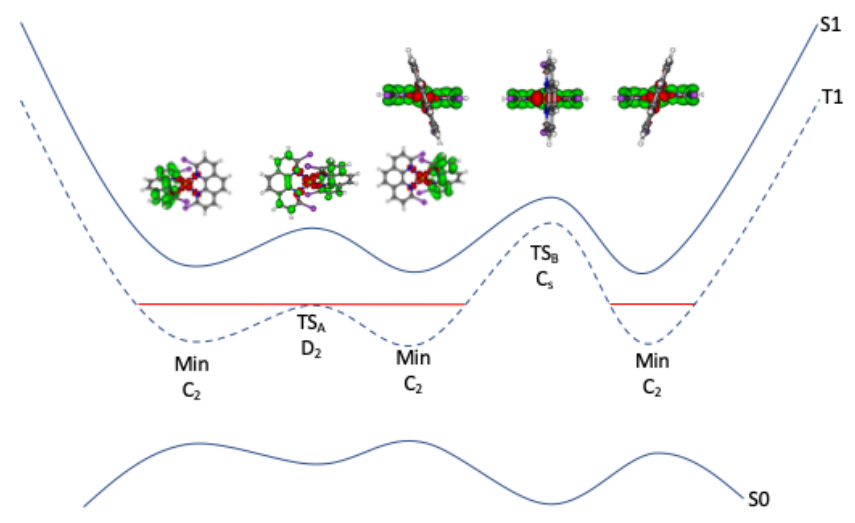

Figure 1. General potential energy profiles connecting the $C_{2}$ degenerate minima of $\left[\mathrm{Cu}\left(2,9-(\mathrm{X})_{2} \text {-phen }\right)_{2}\right]^{+}$together with the evolution of the electronic density differences between $S_{0}$ and $S_{1} / T_{1}$ (in red: reduction, in green: augmentation).

The calculated energy barriers associated to $\mathrm{TS}_{\mathrm{A}}$ are negligible whatever the state is $T_{1}$ (Table 2 ) or $S_{1}$ (Table $S 2$, SI section) nearly vanishing with entropy as illustrated for $T_{1}$ (Table 2). This corroborates the hypothesis of Tahara et al. ${ }^{[5-\mathrm{a}, \mathrm{5e}]}$ of a metastable precursor state with shallow minima generated by PJT instability. In all complexes the only significant geometry changes are the expected $\mathrm{Cu}-\mathrm{N}$ bonds breathing with length variations less than $0.06 \AA$ accompanied by a minor $A-C u-B$ bending for the iodide complex (Table 1 and Table S1, SI section).

The calculated energy barriers correlated to $\mathrm{TS}_{\mathrm{B}}$ and connecting the $T_{1} C_{2}$ flattened structures vary strongly with the $X$ substituent from $\Delta G=12.6 \mathrm{kcal} \mathrm{mol}^{-1}(\mathrm{X}=\mathrm{H})$ to $\Delta \mathrm{G}=1.3 \mathrm{kcal} \mathrm{mol}^{-1}(\mathrm{X}=\mathrm{I})$. 
The bending of the A-Cu-B angle $\left(\sim 20^{\circ}\right)$ is mainly controlled by steric effects and follows the predictable trends with larger angular deformations in $\mathrm{F}, \mathrm{H}$ and $\mathrm{CN}$ that decrease within the halide series from I to $\mathrm{F}$. This geometry change is accompanied by the shortening/lengthening of the $\mathrm{Cu}-\mathrm{N}$ bond lengths.

The Gibbs free energy is not accessible for $S_{1}$ because of TDDFT based computations. However, comparison between $\mathrm{TS}_{\mathrm{B}}$ potential energy barriers $\Delta E$ calculated for $T_{1}$ and $S_{1}$ at the TDDFT level (Table 3) points to similar values for the hydride (14.2 vs. $13.3 \mathrm{kcal} \mathrm{mol}^{-1}$ ) substituted complex and significantly lower barriers in $S_{1}$ for the other molecules comprised between 7.0 kcal mol ${ }^{-1}$ (vs. $10.0 \mathrm{kcal} \mathrm{mol}^{-1}$ in $\mathrm{T}_{1}$ ) in the fluoride complex and $1.0 \mathrm{kcal} \mathrm{mol}^{-1}$ (vs. $3.1 \mathrm{kcal} \mathrm{mol}^{-1}$ in $\mathrm{T}_{1}$ ) in the iodide one. The largest difference occurs in the $\mathrm{CN}$ substituted complex with a calculated barrier of $2.3 \mathrm{kcal} \mathrm{mol}^{-1}$ in $\mathrm{S}_{1}$ and $10.0 \mathrm{kcal} \mathrm{mol}^{-1}$ in $\mathrm{T}_{1}$.

The specific electronic behaviour of the cyano-substituted complex is due to the occurrence of inter-ligand and $\mathrm{X} / \mathrm{Cu}$ interactions in the $\mathrm{TS}_{B}$ structures. These interactions together with the A-Cu-B angle bending lead to opposite polarisations of the electronic densities associated to the $S_{1}$ and $T_{1}$ excited states (Figure S3, SI section). This effect is minor in all complexes except for [Cu(2,9-(CN) ${ }_{2}$-phen $\left.)_{2}\right]^{+}$(Figure 2) for which this phenomena generates a significantly higher $\mathrm{TS}_{\mathrm{B}}$ barrier in $\mathrm{T}_{1}$.
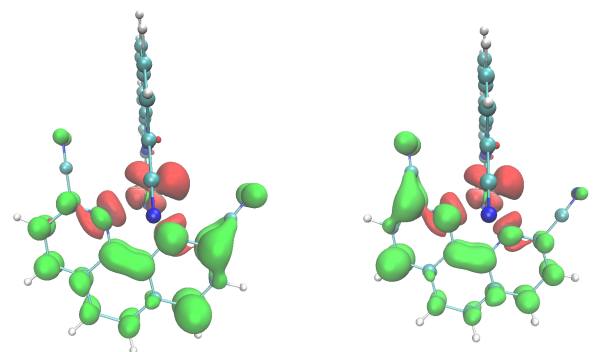

Figure 2. Electron density difference between ground and excited state in $\left[\mathrm{Cu}\left(2,9-(\mathrm{CN})_{2} \text {-phen }\right)_{2}\right]^{+}$complex at $\mathrm{TS}_{\mathrm{B}}$ geometry in $\mathrm{S}_{1}$ (left) and $\mathrm{T}_{1}$ (right) states (In red: reduction; in green: augmentation).

Table 3. TD-DFT calculated transition state $\left(\mathrm{TS}_{\mathrm{A}}\right.$ and $\left.\mathrm{TS}_{\mathrm{B}}\right)$ potential energy $(\Delta E)$ differences in kcal mol ${ }^{-1}$ along the $T_{1}$ and $S_{1}$ potential energy profile computed with ADF [Ref. 17].

\begin{tabular}{ccccc}
\hline & & $\mathrm{T}_{1}$ & & $\mathrm{~S}_{1}$ \\
$\mathrm{X}$ & $\mathrm{TS}_{\mathrm{A}}$ & $\mathrm{TS}_{\mathrm{B}}$ & $\mathrm{TS}_{\mathrm{A}}$ & $\mathrm{TS}_{\mathrm{B}}$ \\
$\mathrm{H}$ & - & 14.4 & 0.3 & 13.3 \\
$\mathrm{~F}$ & 0.5 & 10.0 & 1.6 & 7.0 \\
$\mathrm{Cl}$ & 1.0 & 5.8 & 2.0 & 2.6 \\
$\mathrm{Br}$ & 1.0 & 4.9 & 2.3 & 2.2 \\
$\mathrm{I}$ & 1.4 & 3.1 & 2.1 & 1.0 \\
$\mathrm{Me}$ & 0.8 & 6.1 & 2.5 & 2.7 \\
$\mathrm{CN}$ & - & 10.0 & 0.6 & 2.3 \\
\hline
\end{tabular}

Accordingly, the potential energy profiles associated to the $S_{1}$ and $T_{1}$ excited states of $\left[\mathrm{Cu}\left(2,9-(\mathrm{X})_{2} \text {-phen }\right)_{2}\right]^{+}$(Figure 1 ) run more or less in parallel with more shallow minima in $S_{1}$ where both $\mathrm{TS}_{\mathrm{A}}$ and $\mathrm{TS}_{\mathrm{B}}$ are characterized by nearly negligible energy barriers except for $\left[\mathrm{Cu}\left(2,9-(\mathrm{H})_{2}-\text { phen }\right)_{2}\right]^{+}$and $\left[\mathrm{Cu}\left(2,9-(\mathrm{F})_{2^{-}}\right.\right.$ phen $\left.)_{2}\right]^{+}$in which the inter-ligand and $\mathrm{Cu} / \mathrm{X}$ interactions discussed above are almost absent. The shape of the potential energy profiles corroborates the early time dynamics (sub-ps) discussed both experimentally ${ }^{[5]}$ and theoretically ${ }^{[6]}$ for the $\left[\mathrm{Cu}(\mathrm{dmp})_{2}\right]^{+}$complex, namely a two time-constant kinetics $\tau_{1}=$ $100-800 \mathrm{fs}$ corresponding to the phen distortion, most probably occurring along the $S_{1}$ potential energy profile and $\tau_{2}=7.4-15 \mathrm{ps}$ associated to the triplet state population. Quantum dynamics simulations performed on $\left[\mathrm{Cu}(\mathrm{dmp})_{2}\right]^{+}$have shown that the flattening of the ligands associated to the PJT distortion enters into competition with sub-ps intersystem crossing to $T_{1}{ }^{[6 a]}$ From the energetics and SOC reported in the next section we might infer a spin-vibronic mechanism of ultra-fast decay with vibronic coupling emerging from active dominant normal modes along which $\mathrm{S}_{1} / \mathrm{T}_{1}$ crossings are generated. Direct quantum mechanics/molecular mechanics (QM/MM) Born-Oppenheimer (BO) simulations in acetonitrile point to an early time ( $110 \mathrm{fs})$ dynamics, not very sensitive to the solvent, whereas at longer time-scale ( $1.2 \mathrm{ps})$ interplay between solvent molecules and flattening process does occur. ${ }^{[6]]}$

$S_{1}-T_{1}$ energy gap, spin-orbit coupling and luminescence properties. In order to obtain quantitative data for the prediction of luminescence and TADF properties of the $\mathrm{Cu}(\mathrm{I})$ phensubstituted investigated complexes we have computed at the TD-DFT level the $\Delta E_{S 1-T 1}$ singlet/triplet energy splitting, the $S_{1} / T_{1}$ SOC and the emission wavelengths at the $T_{1}$ critical structures $\left(C_{2}, T_{A}, T S_{B}\right)$. The emission wavelengths and associated oscillator strengths at the $S_{1}$ critical structures $\left(C_{2}, T_{A}, T_{B}\right)$ have been calculated as well and reported in Table 4 .

Table 4. TD-DFT calculated $\Delta \mathrm{E}_{\mathrm{S} 1-\mathrm{T} 1}$ (in eV), SOC (in $\mathrm{cm}^{-1}$ ), $\lambda^{\mathrm{em}}$ (in $\mathrm{nm}$ ) and oscillator strengths $f$ associated to the $\mathrm{T}_{1}$ and $\mathrm{S}_{1} \mathrm{C}_{2}, \mathrm{TS}_{\mathrm{A}}$ and $\mathrm{TS}_{\mathrm{B}}$ critical structures depicted in Figure 1. (Computation with ADF [Ref. 17].

\begin{tabular}{|c|c|c|c|c|c|c|}
\hline \multirow[b]{2}{*}{$x$} & \multirow[t]{2}{*}{$\begin{array}{l}\text { Critical } \\
\text { Structure }\end{array}$} & \multicolumn{2}{|c|}{$\begin{array}{c}\text { Opt- } \mathrm{T}_{1} \\
\text { Structure }\end{array}$} & \multicolumn{3}{|c|}{$\begin{array}{r}\text { Opt-S } \\
\text { Structure }\end{array}$} \\
\hline & & $\Delta \mathrm{E}_{\mathrm{S} 1-\mathrm{T} 1}$ & soc & $\lambda^{\mathrm{em}}$ & $\lambda^{\mathrm{em}}$ & $f$ \\
\hline \multirow[t]{3}{*}{$\mathrm{H}$} & $\mathrm{C}_{2}$ & 0.46 & 26 & 1746 & 1725 & $3.510^{-5}$ \\
\hline & $\mathrm{TS}_{\mathrm{A}}$ & 0.47 & 11 & 1532 & 1697 & 0.0 \\
\hline & $\mathrm{TS}_{\mathrm{B}}$ & 0.17 & 0.1 & 741 & 668 & $3.810^{-6}$ \\
\hline \multirow[t]{3}{*}{$\mathrm{F}$} & $\mathrm{C}_{2}$ & 0.39 & 38 & 1057 & 924 & $7.110^{-3}$ \\
\hline & $\mathrm{TS}_{\mathrm{A}}$ & 0.38 & 2.0 & 961 & 905 & 0.0 \\
\hline & $\mathrm{TS}_{\mathrm{B}}$ & 0.08 & 0.7 & 653 & 620 & $2.310^{-6}$ \\
\hline \multirow[t]{3}{*}{$\mathrm{Cl}$} & $\mathrm{C}_{2}$ & 0.37 & 52 & 902 & 742 & $1.810^{-2}$ \\
\hline & $\mathrm{TS}_{\mathrm{A}}$ & 0.35 & 8.0 & 815 & 654 & $8.210^{-2}$ \\
\hline & $\mathrm{TS}_{\mathrm{B}}$ & 0.16 & 0.6 & 725 & 655 & $1.110^{-5}$ \\
\hline \multirow[t]{3}{*}{$\mathrm{Br}$} & $\mathrm{C}_{2}$ & 0.35 & 53 & 870 & 726 & $1.910^{-2}$ \\
\hline & $\mathrm{TS}_{\mathrm{A}}$ & 0.33 & 7.0 & 789 & 650 & $7.310^{-2}$ \\
\hline & $\mathrm{TS}_{\mathrm{B}}$ & 0.16 & 0.7 & 732 & 664 & $3.910^{-5}$ \\
\hline \multirow[t]{3}{*}{ I } & $\mathrm{C}_{2}$ & 0.31 & 50 & 835 & 705 & $1.310^{-2}$ \\
\hline & $\mathrm{TS}_{\mathrm{A}}$ & 0.23 & 6.0 & 750 & 643 & $5.910^{-2}$ \\
\hline & $\mathrm{TS}_{\mathrm{B}}$ & 0.16 & 1.8 & 741 & 672 & $3.010^{-5}$ \\
\hline \multirow[t]{2}{*}{$\mathrm{Me}$} & $\mathrm{C}_{2}$ & 0.40 & 55 & 982 & 800 & $1.610^{-2}$ \\
\hline & $\mathrm{TS}_{\mathrm{A}}$ & 0.42 & 9.0 & 897 & 665 & $8.610^{-2}$ \\
\hline
\end{tabular}




\begin{tabular}{lllllll} 
& $\mathrm{TS}_{\mathrm{B}}$ & 0.17 & 0.2 & 737 & 665 & $1.710^{-6}$ \\
& & & & & & \\
$\mathrm{CN}$ & $\mathrm{C}_{2}$ & 0.43 & 2.0 & 1029 & 859 & $8.910^{-3}$ \\
& $\mathrm{TS}_{\mathrm{A}}$ & 0.44 & 0.7 & 1036 & 817 & $1.410^{-2}$ \\
& $\mathrm{TS}_{\mathrm{B}}$ & 0.17 & 0.6 & 706 & 654 & $3.710^{-5}$ \\
\hline
\end{tabular}

As pointed out by previous studies flattening distortion significantly weakens SOC as illustrated by the values calculated at $\mathrm{TS}_{\mathrm{A}}$ (Table 4). $\left[\mathrm{e}^{5 \mathrm{e} f]}\right.$ Further distortion, as metal coordination breathing, results in SOC increase at the $\mathrm{C}_{2}$ minima (Figure 1) from $26 \mathrm{~cm}^{-1}$ in the hydride complex until $55 \mathrm{~cm}^{-1}$ in $\left[\mathrm{Cu}(\mathrm{dmp})_{2}\right]^{+}$but remain negligible at the TS structures, especially at the $T S_{B}$ one where $S_{1}$ and $T_{1}$ become close in energy $\left(\Delta E_{S 1-}\right.$ $\mathrm{T}_{1}<0.2 \mathrm{eV}$ ). In contrast, significantly larger $\mathrm{S}_{1}-\mathrm{T}_{1}$ energy gaps characterize the $\mathrm{C}_{2}$ and $\mathrm{TS}_{\mathrm{A}}$ structures. Oscillator strengths associated to the different structures in $\mathrm{S}_{1}$ give an estimate of the $S_{0}$ electronic ground state coupling with $S_{1}$. For symmetry reasons $f$ is small in the hydride and fluoride complexes, which possess structures close to the $A$ forbidden symmetry of the $D_{2}$ point group whereas the other complex structures converge to the $B_{3}$-like allowed symmetry. Consequently when moving freely on the flat $\mathrm{S}_{1}$ PES the $\left[\mathrm{Cu}\left(2,9-(\mathrm{X})_{2} \text {-phen }\right)_{2}\right]^{+}$complexes with $\mathrm{X}=$ $\mathrm{Cl}, \mathrm{Br}, \mathrm{Me}, \mathrm{CN}$ and I to a lesser extent, potentially fluoresce from the $\mathrm{C}_{2}$ minima and $\mathrm{TS}_{\mathrm{A}}$ structures at short time scales within $640-860 \mathrm{~nm}$ range. In the hydride and fluoride complexes the low probability of fluorescence combined with rather large $T_{B}$ energy barriers (Table 2 and 3 ), trapping events in the $C_{2}$ minima are more likely with efficient transfer to the $T_{1}$ PES by SOC. For these two complexes, either TADF mechanism is not favourable because of the rather large $\Delta \mathrm{E}_{\mathrm{S} 1-\mathrm{T} 1}$ energy gap (Table 4) and high $T_{B}$ energy barriers on $T_{1}$ PES preventing any back ISC to $S_{1}$, or it is inefficient because of the low fluorescence probability. In the other complexes $(\mathrm{X}=\mathrm{Cl}, \mathrm{Br}, \mathrm{I}, \mathrm{Me}, \mathrm{CN})$ the close proximity of $S_{1}$ and $T_{1}$ at the $T_{B}$ structures may activate the early time population of $T_{1}$ by vibronic effects viewing the small values of SOC at these transition states leading to shortlived phosphorescence within 700-740 nm. At longer time scales, when the population of $T_{1}$ is substantial and because of the presence of non-negligible $T S_{B}$ energy barriers on the $T_{1} P E S$, increasing temperature may have some effects on reverse ISC ( $r$-ISC) for a TADF behaviour as recently shown for the chloride and bromide complexes. ${ }^{[4]}$ This back population to $S_{1}$ is probably driven by a spin-vibronic mechanism ${ }^{[8]}$ and lead to blue-shifted short-lived emission between 650-670 nm in agreement with most experimental data available on this class of $\mathrm{Cu}(\mathrm{I})$ complexes. ${ }^{[3],[4],[9]}$ However the flat PES associated to $[\mathrm{Cu}(2,9-$ $(\mathrm{I})_{2}$-phen $\left.)_{2}\right]^{+}$with nearly no energy barrier, especially on $\mathrm{S}_{1} \mathrm{PES}$, explain undoubtedly an opposite thermal effect, namely an increase of luminescence together with a small red-shift by 20 $\mathrm{nm}$ when decreasing the temperature, correlated to an "antiTADF" mechanism. ${ }^{[4]}$ Indeed, whatever the temperature is, the system will move freely on the $S_{1}$ and $T_{1}$ PES increasing the contribution of the weakly $S_{1} / S_{0}$ coupled $T S_{B}$ conformation to the average structure resulting in inefficient TADF.

Born-Oppenheimer dynamics on the $T_{1}$ PES of $\left[\mathrm{Cu}\left(2,9-(\mathrm{Br})_{2}-\right.\right.$ phen $\left.)_{2}\right]^{+}$. The evolutions of the $\mathrm{Cu}-\mathrm{A}, \mathrm{Cu}-\mathrm{B}$ distances and $\mathrm{C} \alpha-\mathrm{A}-$ $\mathrm{B}-\mathrm{C} \alpha$ angle in the bromide substituted complex as function of time over 11 ps at $300 \mathrm{~K}$ (NVT ensemble) are depicted in Figure 3 and Figures S4, S5 (SI section).

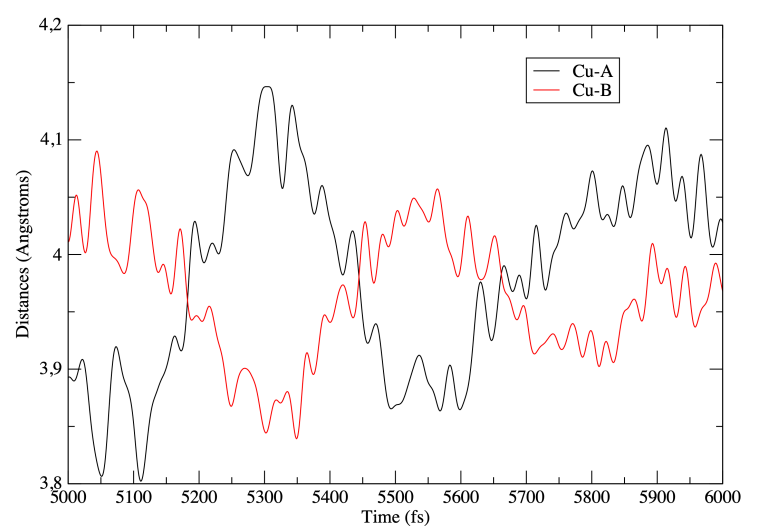

Figure 3. Evolution of the $\mathrm{Cu}-\mathrm{A}$ and $\mathrm{Cu}-\mathrm{B}$ distances in the 5000 to $6000 \mathrm{fs}$ window. See Figure S5 for the complete dynamics.

Despite an aborted attempt at about 1.5 ps no exchange between the flattened conformers is observed (Figure S4). In contrast and as expected from the low $\mathrm{TS}_{\mathrm{A}}$ energy barriers rather fast dynamics characterize the $\mathrm{Cu}-\mathrm{A}$ and $\mathrm{Cu}-\mathrm{B}$ distance variations (Figure S5). Figure 3 represents a zoom within the 5 ps - 6 ps time window that put in evidence the backwards and forwards motion of the phenanthroline ligands within a period of 200-300 fs. This confirms the metastable character of the $C_{2}$ structures.

\section{Conclusion}

The phenanthroline substituent effects on the nuclear motions that control the photophysics of $\left[\mathrm{Cu}\left(2,9-(\mathrm{X})_{2} \text {-phen }\right)_{2}\right]^{+}$complexes beyond picosecond timescale are analyzed on the basis of potential energy profiles $\left(S_{1}\right.$ and $\left.T_{1}\right)$ and Gibbs energy profiles $\left(T_{1}\right)$ that connect the $C_{2}$ minima generated by electronic charge transfer on one or the other phananthroline and by the flattening distortion. The static picture points to nearly flat PES for the first process $\left(\mathrm{TS}_{\mathrm{A}}\right)$ whereas significant and substituent dependent energy barriers characterize the flattening $\left(\mathrm{TS}_{\mathrm{B}}\right)$ of the molecules upon excitation into the MLCT band. Subsequent BO dynamics on $T_{1}$ confirm an ultrafast free backwards and forwards motion of the phenanthroline ligands within a period of 200-300 fs. This indicates that the $\mathrm{TS}_{\mathrm{A}}$ structure is statistically more representative than the $\mathrm{C}_{2}$ conformations and more relevant for contributing to the emission properties of the complexes. Depending on the molecule, similar assumption can be made with the $\mathrm{TS}_{\mathrm{B}}$ structure.

Further analysis based on SOC, $S_{1} / T_{1}$ energy gaps and oscillator strengths put in evidence similar behaviors for halide$(\mathrm{X}=\mathrm{Cl}, \mathrm{Br}, \mathrm{I})$, methyl- and cyano-phenanthroline substituted complexes, namely potential fluorescence from $\mathrm{C}_{2}$ and $\mathrm{TS}_{\mathrm{A}}$ minima at short time scales within $640-860 \mathrm{~nm}$ followed by early time population of $T_{1}$ by vibronic effects leading to short-lived phosphorescence within 700-740 nm. At longer time scales, when the population of $T_{1}$ is significant, the presence of nonnegligible $T S_{B}$ energy barriers on the $T_{1}$ PES makes the temperature activation of $r$-ISC suitable for a TADF behavior leading to blue-shifted short-lived emission between 650-670 nm. This process appears to be less efficient for the iodide 
substituted compound because of weakly coupled $S_{1} / S_{0}$ states at regions of the PES predominantly visited because of their exceptional flatness. In contrast, the hydride and fluoride complexes get trapped into the $\mathrm{C}_{2}$ minima and subsequently to $T_{1}$ because of low $S_{1} / S_{0}$ coupling and rather large $T S_{B}$ energy barriers on $\mathrm{S}_{1}$. For these two complexes TADF mechanism is not favorable and prevented by rather large $\Delta \mathrm{E}_{\mathrm{S} 1-\mathrm{T} 1}$ energy gap and high $\mathrm{TS}_{\mathrm{B}}$ energy barriers on $\mathrm{T}_{1}$.

Further simulations based on non-adiabatic quantum dynamics should put in evidence spin-vibronic effects that could involve upper excited states to bridge the gap between the nearly static analyses performed on $S_{1} / T_{1}$ only and modeling of $S_{n}$ to $S_{1}$ ultrafast decay.

\section{Computational Details}

A first series of DFT/B3LYP ${ }^{[10]}$ optimizations of the $S_{0}, S_{1}$ and $T_{1}$ minima and TS connecting them have been performed in dichloromethane (DCM) within the polarized continuum mode $(P C M)^{[11]}$ using def2-TZVP sets for all atoms ${ }^{[12]}$ and associated pseudopotential for iodine. Dispersion forces were introduced through the empirical GD3 correction. ${ }^{[13]}$ The critical geometries were validated by frequency analysis within the harmonic approximation whereas symmetry has been taken into account under $D_{2}, C_{2}$ and $C_{s}$ point group constraints. Non-covalent interactions were studied by mean of NCIPLOT package ${ }^{[14]} \mathrm{A}$ second series of TD-DFT(B3LYP) calculations using triple- $\zeta$ basis sets ${ }^{[15]}$ and more specifically dedicated to $S_{1}$ potential energy profile, wavelengths of emission, spin-orbit couplings and $\mathrm{S}_{1}-\mathrm{T}_{1}$ energy differences has been performed in the same conditions (solvent, dispersion correction, symmetry constraints). The electronic structure calculations have been carried out with Gaussian09 ${ }^{[16]}$ and ADF2019 ${ }^{[17]}$ quantum chemistry softwares. Born-Oppenheimer dynamic has been performed on the $\left[\mathrm{Cu}\left(2,9-(\mathrm{Br})_{2}-\text { phen }\right)_{2}\right]^{+}$complex using CP2K package. ${ }^{[18]}$ The simulation was run in NVT ensemble at $300 \mathrm{~K}$ at DFT level of theory using the PBE functional ${ }^{[19]}$ with DFTD3 dispersion correction. ${ }^{[13]}$ The simulation was done in gas phase in a cubic cell with $A, B$ and $C$ cell vectors of $28 \AA$. Thermostat was controlled through a CSVR thermostat. The simulation has been performed on the $T_{1}$ PES with a time step of $1 \mathrm{fs}$ for $11 \mathrm{ps}$ after an equilibration run of $5 \mathrm{ps}$.

Keywords: Copper(I) phenanthroline - Excited state structure• Free energy profile $\cdot$ Density functional theory $\cdot$ Substituent effects

[1] a) N. Armaroli, Chem. Soc. Rev. 2001, 30, 113-124; b) N. Armaroli, G. Accorsi, F. Cardinali, A. Listorti, Top. Curr. Chem. 2007, 280, 69-115; (c) M. Ruthkosky, C. A. Kelly, F. N. Castellano, G. J. Meyer, Chem. Rev. 1998, 171, 309-322; (d) J. M. Kern, J. -P. Sauvage, J. Chem. Soc. Commun. 1987,546-548.

[2] (a) M. K. Eggleston, D. R. McMillin, K. S. Koenig, A. J. Pallenberg, Inorg. Chem. 1997, 36, 172-176; (b) C. T. Cunningham, K. L. H. Cunningham, J. F. Michalec, D. R. McMillin, Inorg. Chem. 1999, 38, 4388-4392.

[3] (a) S. Garakyaraghi, P. D. Crapps, C. E. McCusker, F. N. Castellano, Inorg. Chem. 2016, 55, 10628-10636; (b) C. E. McCusker, F. N. Castellano, Inorg. Chem. 2013, 52, 8114-8120; (c) M. W. Mara, K. A. fransted, L. X. Chen, Coord. Chem. Rev. 2015, 282-283, 2-18; (d) A. Lavie-Cambot, M. Cantuel, Y. Leydet, G. Jonusauskas, D. M. Bassani, N. D. McClenaghan, Coord. Chem. Rev. 2008, 252, 2572-2584.
[4] S. Brown-Xu, M. Fumanal, C. Gourlaouen, L. Gimeno, A. Quatela, C. Thobie-Gauthier, E. Blart, A. Planchat, F. Riobé, C. Monnereau, L. X. Chen, C. Daniel, Y. Pellegrin, Inorg. Chem. 2019, 58, 7730-7745.

[5] (a) M. Iwamura, H. Watanabe, K. Ishii, S. Takeuchi, T. Tahara, J. Am Chem. Soc. 2011, 133, 7728-7736; (b) M. Iwamura, S. Takeuchi, T. Tahara, J. Am. Chem. Soc. 2007, 129, 5248-5256; (c) M. Iwamura, S. Takeuchi, T. Tahara, Phys. Chem. Chem. Phys. 2014, 16, 4143-5154; (d) S. Garakyaraghi, E. O. Danilov, C. E. McCusker, F. N. Castellano, J. Phys. Chem. A 2015, 119, 3181-3193; (e) M. Iwamura, S. Takeuchi, T. Tahara, Acc. Chem. Res. 2015, 48, 782-791; (f) G. B. Shaw, C. D. grant, H. Shirota, E. W. Castner, G. J. Meyer, L. X. Chen, J. Am. Chem. Soc. 2007, 129, 2147-2160; (g) L. X. Chen, G. B. Shaw, I. Novozhilova, T. Liu, G. Jennings, K. Attenkofer, G. J. Meyer, P. Coppens, J. Am. Chem. Soc. 2003, 125, 7022-7034.

[6] (a) G. Capano, M. Chergui, U. Rothlisberger, I. Tavernelli; T. J. Penfold, J. Phys. Chem. A 2014, 118, 9861-9869; (b) L. Du, Z. Lan, Phys. Chem. Chem. Phys. 2016, 18, 7641-7650; (c) G. Levi, E. Biasin, A. O. Dohn, H. Jonsson, Phys. Chem. Chem. Phys. 2020, 22, 748-757.

[7] C. T. Cunningham, J. J. More, K. L. H. Cunningham, P. E. Fanwick, D. R. McMillin, Inorg. Chem. 2000, 39, 3638-3644; (b) W. L. Parker, G. A. Crosby, J. Phys. Chem. 1989, 93, 5692-5696; (c) A. J. Blake, S. J. Hill, P. Hubberstey, W. -S. Li, J. Chem. Soc., Dalton Trans. 1998, 909-916; (d) W. T. Eckenhoff, T. Pintauer, Acta Crystallogr., Sect. E: Struct. Rep. Online 2007, 63, m800-m802.

[8] T. J. Penfold, E. Gindensperger, C. Daniel, C. M. Marian, Chem. Rev. 2018, 118, 6975-7625.

[9] (a) J. R. Kirchhoff, R. E. Gamache, M. W. Blaskie, A. A. Del Pagio, R. K. Lengel, D. R. McMillin, Inorg. Chem. 1983, 22, 2380-2384; (b) R. M. Everly, D. R. McMillin, J. Phys. Chem. 1991, 95, 9071-9075; (c) D. felder, J. -F. Nierengarten, F. Barigelletti, B. Ventura, N. Armaroli, J. Am. Chem. Soc. 2001, 123, 6291-6299.

[10] A. D. Becke, J. Chem. Phys. 1993, 98, 5648-5652.

[11] S. Miertuš, E. Scrocco, J. Tomasi, Chem. Phys. 1981, 55, 117-29.

[12] F. Weigend, R. Ahlrichs, Phys. Chem. Chem. Phys. 2005, 7, 3297-305.

[13] S. Grimme, J. Antony, S. Ehelich, H. Krieg, J. Chem. Phys. 2010, 132, 154104.

[14] J. Contreras-Garcia, E. Johnson, S. Keinan, R. Chaudret, J-P Piquemal, D. Beratan, W. Yang, J. Chem. Theor. Comp. 2011, 7, 625-632.

[15] E. van Lenthe, E.J. Baerends, J. of Comput. Chem. 2003, 24, 1142 $-1156$.

[16] Gaussian 09, Revision A.02, M. J. Frisch, G. W. Trucks, H. B. Schlegel, G. E. Scuseria, M. A. Robb, J. R. Cheeseman, G. Scalmani, V. Barone, G. A. Petersson, H. Nakatsuji, X. Li, M. Caricato, A. Marenich, J. Bloino, B. G. Janesko, R. Gomperts, B. Mennucci, H. P. Hratchian, J. V. Ortiz, A. F. Izmaylov, J. L. Sonnenberg, D. Williams-Young, F. Ding, F. Lipparini, F. Egidi, J. Goings, B. Peng, A. Petrone, T. Henderson, D. Ranasinghe, V. G. Zakrzewski, J. Gao, N. Rega, G. Zheng, W. Liang, M. Hada, M. Ehara, K. Toyota, R. Fukuda, J. Hasegawa, M. Ishida, T. Nakajima, Y. Honda, O. Kitao, H. Nakai, T. Vreven, K. Throssell, J. A. Montgomery, Jr., J. E. Peralta, F. Ogliaro, M. Bearpark, J. J. Heyd, E. Brothers, K. N. Kudin, V. N. Staroverov, T. Keith, R. Kobayashi, J. Normand, K. Raghavachari, A. Rendell, J. C. Burant, S. S. Iyengar, J. Tomasi, M. Cossi, J. M. Millam, M. Klene, C. Adamo, R. Cammi, J. W. Ochterski, R. L. Martin, K. Morokuma, O. Farkas, J. B. Foresman, and D. J. Fox, Gaussian, Inc., Wallingford CT, 2016.

[17] ADF 2019.3, SCM, Theoretical Chemistry, Vrije Universiteit, Amsterdam, The Netherlands, http://www.scm.com. Optionally, you may add the following list of authors and contributors: E.J. Baerends, T. Ziegler, A.J. Atkins, J. Autschbach, O. Baseggio, D. Bashford, A. Bérces, F.M. Bickelhaupt, C. Bo, P.M. Boerrigter, L. Cavallo, C. Daul, D.P. Chong, D.V. Chulhai, L. Deng, R.M. Dickson, J.M. Dieterich, D.E. Ellis, M. van Faassen, L. Fan, T.H. Fischer, A. Förster, C. Fonseca Guerra, M. Franchini, A. Ghysels, A. Giammona, S.J.A. van Gisbergen, A. Goez, A.W. Götz, J.A. Groeneveld, O.V. Gritsenko, M. Grüning, S. Gusarov, F.E. Harris, P. van den Hoek, Z. Hu, C.R. Jacob, H. Jacobsen, L. Jensen, L. Joubert, J.W. Kaminski, G. van Kessel, C. König, F. Kootstra, A. Kovalenko, M.V. Krykunov, E. van Lenthe, D.A. McCormack, A. Michalak, M. Mitoraj, S.M. Morton, J. Neugebauer, V.P. 
Nicu, L. Noodleman, V.P. Osinga, S. Patchkovskii, M. Pavanello, C.A. Peeples, P.H.T. Philipsen, D. Post, C.C. Pye, H. Ramanantoanina, P. Ramos, W. Ravenek, J.I. Rodríguez, P. Ros, R. Rüger, P.R.T. Schipper, D. Schlüns, H. van Schoot, G. Schreckenbach, J.S. Seldenthuis, M. Seth, J.G. Snijders, M. Solà, M. Stener, M. Swart, D. Swerhone, V. Tognetti, G. te Velde, P. Vernooijs, L. Versluis, L. Visscher, O. Visser, F. Wang, T.A. Wesolowski, E.M. van Wezenbeek, G. Wiesenekker, S.K. Wolff, T.K. Woo, A.L. Yakovlev; G.te Velde, F.M. Bickelhaupt, E.J. Baerends, C. Fonseca Guerra, S.J.A. van Gisbergen, J.G. Snijders and T. Ziegler, J. Comput. Chem. 2001, 22, 931-967.

[18] T. D. Kühne, M. lannuzzi, M. Del Ben, V. V. Rybkin, P. Seewald, F. Stein, T. Laino, R. Z. Khaliullin, O. Schütt, F. Schiffmann, D. Golze, J. Wilhelm, S. Chulkov, M. H. Bani-Hashemian, V. Weber, U. Borštnik, M. Taillefumier, A. S. Jakobovits, A. Lazzaro, H. Pabst, T. Müller, R. Schade, M. Guidon, S. Andermatt, N. Holmberg, G. K. Schenter, A Hehn, A. Bussy, F. Belleflamme, G. Tabacchi, A. Glöß, M. Lass, I. Bethune, C. J. Mundy, C. Plessl, M. Watkins, J. VandeVondele, M. Krack, and J. Hutter, J. Chem. Phys. 2020, 152, 194103.

[19] J. P. Perdew, K. Burke, M. Ernzerhof, Phys. Rev. Lett. 1996, 77, 3865; J. P. Perdew, K. Burke, M. Ernzerhof, Phys. Rev. Lett. 1997, 78, 1396. 


\section{Entry for the Table of Contents}

Insert graphic for Table of Contents here.

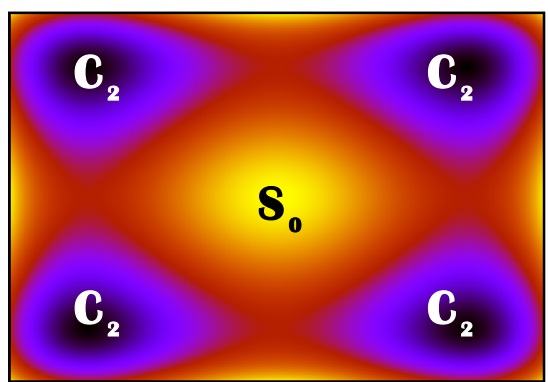

The over picosecond timescale photophysics of a series of copper(I) X-substituted phenanthroline complexes is interpreted on the basis of Gibbs free energy and potential energy profiles of the lowest $S_{1}$ and $T_{1}$ electronic excited states. Born-Oppenheimler dynamics over 10 ps evidence the backwards and forwards motion of the phenanthroline ligands within a period of 200-300 fs. 
Supporting Information

Substituent effects on the photophysical properties of 2,9substituted phenanthroline copper(I) complexes: a static theoretical investigation

Christophe Gourlaouen, ${ }^{*[a]}$ Ai Hamano, ${ }^{[a, b]}$ Keiko Takano,${ }^{[b]}$ Chantal Daniel ${ }^{\star[a]}$

[a] Laboratoire de Chimie Quantique Institute of Chemistry UMR 7177

CNRS/ Strasbourg University

ILB, 4 Rue Blaise Pascal 67008 Strasbourg Cedex

E-mail: gourlaouen@unistra.fr; c.daniel@unistra.fr

[b] Department of Chemistry and Biochemistry, Graduate School of Humanities and Sciences

Ochanomizu University

2-1-1 Otsuka, Bunkyo-ku, Tokyo 112-8610, Japan 
Table S1. Cu-N bond length (in $\AA$ ) of $\left[\mathrm{Cu}\left(2,9-(\mathrm{X})_{2} \text {-phen }\right)_{2}\right]^{+}$complexes in their ground state $\left(\mathrm{D}_{2 \mathrm{D}}\right.$ symmetry).

\begin{tabular}{ccc}
\hline $\mathrm{X}$ & GAUSSIAN & ADF \\
$\mathrm{H}$ & 2.08 & 2.06 \\
$\mathrm{~F}$ & 2.09 & 2.07 \\
$\mathrm{Cl}$ & 2.08 & 2.05 \\
$\mathrm{Br}$ & 2.08 & 2.04 \\
$\mathrm{I}$ & 2.08 & 2.03 \\
$\mathrm{Me}$ & 2.07 & 2.06 \\
$\mathrm{CN}$ & 2.07 & 2.05 \\
\hline
\end{tabular}

Table S2. ADF relevant geometrical parameters of $\left[\mathrm{Cu}\left(2,9-(\mathrm{X})_{2}-\mathrm{phen}\right)_{2}\right]^{+} \mathrm{Cu}-\mathrm{N}$ (in $\AA$ ), $\mathrm{A}-\mathrm{Cu}-\mathrm{B}$ and $\mathrm{C} \alpha-\mathrm{A}-\mathrm{B}-\mathrm{C} \alpha$ (in ${ }^{\circ}$ ) optimized for the $\mathrm{T}_{1} \mathrm{PES}$ minima $\left(C_{2}\right)$ and TS structures, $\operatorname{TS}_{A}\left(D_{2}\right)$ and $\mathrm{TS}_{B}\left(C_{S}\right)$, that connect them

\begin{tabular}{|c|c|c|c|c|c|c|c|c|c|c|c|c|c|c|c|c|c|c|}
\hline \multirow{3}{*}{$x^{a}$} & \multicolumn{9}{|c|}{$\mathrm{S}_{1}$} & \multicolumn{9}{|c|}{$\mathrm{T}_{1}$} \\
\hline & \multicolumn{3}{|c|}{ Cu-N } & \multicolumn{3}{|c|}{ A-Cu-B } & \multicolumn{3}{|c|}{$\mathrm{C} \alpha-\mathrm{A}-\mathrm{B}-\mathrm{C} \alpha$} & \multicolumn{3}{|c|}{ Cu-N } & \multicolumn{3}{|c|}{ A-Cu-B } & \multicolumn{3}{|c|}{$\mathrm{C} \alpha-\mathrm{A}-\mathrm{B}-\mathrm{C} \alpha$} \\
\hline & $\min$ & $\mathrm{TS}_{\mathrm{A}}$ & $\mathrm{TS}_{\mathrm{B}}$ & $\min$ & $\mathrm{TS}_{\mathrm{A}}$ & $\mathrm{TS}_{\mathrm{B}}$ & $\min$ & $\mathrm{TS}_{\mathrm{A}}$ & $\mathrm{TS}_{\mathrm{B}}$ & $\min$ & $\mathrm{TS}_{\mathrm{A}}$ & $\mathrm{TS}_{\mathrm{B}}$ & $\min$ & $\mathrm{TS}_{\mathrm{A}}$ & $\mathrm{TS}_{\mathrm{B}}$ & $\min$ & $\mathrm{TS}_{\mathrm{A}}$ & $\mathrm{TS}_{\mathrm{B}}$ \\
\hline \multirow[t]{4}{*}{$\mathrm{H}$} & 2.01 & 2.03 & 1.95 & 180.0 & 180.0 & 173.7 & 40.1 & 39.6 & 90.0 & 1.99 & 2.01 & 1.95 & 180.0 & 180.0 & 176.8 & 39.9 & 40.2 & 90.0 \\
\hline & 2.01 & 2.03 & 1.96 & & & & & & & 1.99 & 2.01 & 1.95 & & & & & & \\
\hline & 2.07 & 2.03 & 2.15 & & & & & & & 2.04 & 2.01 & 2.15 & & & & & & \\
\hline & 2.07 & 2.03 & 2.15 & & & & & & & 2.04 & 2.01 & 2.15 & & & & & & \\
\hline \multirow[t]{4}{*}{$\mathrm{F}$} & 2.01 & 2.05 & 1.96 & 180.0 & 180.0 & 174.5 & 50.6 & 52.8 & 90.0 & 2.01 & 2.02 & 1.96 & 180.0 & 180.0 & 173.5 & 48.9 & 49.6 & 90.0 \\
\hline & 2.01 & 2.05 & 1.97 & & & & & & & 2.01 & 2.02 & 1.96 & & & & & & \\
\hline & 2.10 & 2.05 & 2.15 & & & & & & & 2.05 & 2.02 & 2.15 & & & & & & \\
\hline & 2.10 & 2.05 & 2.15 & & & & & & & 2.05 & 2.02 & 2.15 & & & & & & \\
\hline \multirow[t]{4}{*}{$\mathrm{Cl}$} & 1.98 & 2.02 & 1.95 & 180.0 & 180.0 & 171.9 & 66.3 & 64.1 & 90.0 & 1.98 & 2.01 & 1.94 & 180.0 & 180.0 & 168.7 & 63.1 & 63.9 & 90.0 \\
\hline & 1.98 & 2.02 & 1.96 & & & & & & & 1.98 & 2.01 & 1.96 & & & & & & \\
\hline & 2.10 & 2.02 & 2.14 & & & & & & & 2.05 & 2.01 & 2.14 & & & & & & \\
\hline & 2.10 & 2.02 & 2.14 & & & & & & & 2.05 & 2.01 & 2.14 & & & & & & \\
\hline \multirow[t]{4}{*}{$\mathrm{Br}$} & 1.98 & 2.01 & 1.94 & 180.0 & 180.0 & 166.9 & 67.6 & 67.1 & 90.0 & 1.98 & 2.00 & 1.93 & 180.0 & 180.0 & 167.0 & 65.7 & 64.8 & 90.0 \\
\hline & 1.98 & 2.01 & 1.96 & & & & & & & 1.98 & 2.00 & 1.96 & & & & & & \\
\hline & 2.09 & 2.01 & 2.12 & & & & & & & 2.04 & 2.00 & 2.12 & & & & & & \\
\hline & 2.09 & 2.01 & 2.12 & & & & & & & 2.04 & 2.00 & 2.12 & & & & & & \\
\hline \multirow[t]{4}{*}{ I } & 1.97 & 2.01 & 1.94 & 180.0 & 177.1 & 169.2 & 73.1 & 69.6 & 90.0 & 1.98 & 2.00 & 1.93 & 180.0 & 177.6 & 168.8 & 68.5 & 69.7 & 90.0 \\
\hline & 1.97 & 2.03 & 1.97 & & & & & & & 1.98 & 2.01 & 1.97 & & & & & & \\
\hline & 2.09 & 2.01 & 2.12 & & & & & & & 2.05 & 2.00 & 2.12 & & & & & & \\
\hline & 2.09 & 2.03 & 2.12 & & & & & & & 2.05 & 2.01 & 2.12 & & & & & & \\
\hline \multirow[t]{4}{*}{$\mathrm{Me}$} & 1.99 & 2.03 & 1.95 & 180.0 & 180.0 & 175.8 & 68.9 & 70.5 & 90.0 & 1.99 & 2.01 & 1.95 & 180.0 & 180.0 & 177.2 & 66.2 & 65.6 & 90.0 \\
\hline & 1.99 & 2.03 & 1.96 & & & & & & & 1.99 & 2.01 & 1.95 & & & & & & \\
\hline & 2.11 & 2.03 & 2.14 & & & & & & & 2.05 & 2.01 & 2.13 & & & & & & \\
\hline & 2.11 & 2.03 & 2.14 & & & & & & & 2.05 & 2.01 & 2.13 & & & & & & \\
\hline \multirow[t]{4}{*}{$\mathrm{CN}$} & 2.02 & 2.04 & 1.95 & 180.0 & 180.0 & 159.2 & 61.2 & 60.6 & 90.0 & 2.01 & 2.01 & 1.94 & 180.0 & 180.0 & 162.6 & 57.3 & 56.9 & 90.0 \\
\hline & 2.02 & 2.04 & 1.97 & & & & & & & 2.01 & 2.01 & 1.95 & & & & & & \\
\hline & 2.06 & 2.04 & 2.15 & & & & & & & 2.02 & 2.01 & 2.15 & & & & & & \\
\hline & 2.06 & 2.04 & 2.15 & & & & & & & 2.02 & 2.01 & 2.15 & & & & & & \\
\hline
\end{tabular}


Table S3. for each complex, energy difference (in kcal mol ${ }^{-1}$ ) between the $D_{2 d} S_{0}$ minima and the different excited. In bold are the states discussed in the main text, being the most stable for each symmetry group and structure.

\begin{tabular}{|c|c|c|c|c|c|c|c|c|c|c|c|c|c|c|c|c|}
\hline & \multicolumn{8}{|c|}{ S1 } & \multicolumn{8}{|c|}{$\mathrm{T} 1$} \\
\hline & \multicolumn{2}{|c|}{$\operatorname{Min}\left(C_{2}\right)$} & \multicolumn{4}{|c|}{$\mathrm{TS}_{\mathrm{A}}\left(\mathrm{D}_{2}\right)$} & \multicolumn{2}{|c|}{$\mathrm{TS}_{\mathrm{B}}\left(\mathrm{C}_{\mathrm{s}}\right)$} & \multicolumn{2}{|c|}{$\operatorname{Min}\left(C_{2}\right)$} & \multicolumn{4}{|c|}{$\mathrm{TS}_{\mathrm{A}}\left(\mathrm{D}_{2}\right)$} & \multicolumn{2}{|c|}{$\mathrm{TS}_{\mathrm{B}}\left(\mathrm{C}_{\mathrm{s}}\right)$} \\
\hline$X$ & S1A & S1B & $\mathrm{S} 1 \mathrm{~A}$ & S1B1 & S1B2 & S1B3 & S1' & S1" & $\mathrm{S} 1 \mathrm{~A}$ & S1B & S1A & S1B1 & S1B2 & S1B3 & S1' & S1" \\
\hline $\mathrm{H}$ & 35.1 & 42.4 & 35.4 & 43.1 & 45.2 & 40.4 & 55.1 & 48.4 & 30.2 & 41.5 & 30.2 & 42.1 & 44.2 & 36.7 & 47.1 & 44.4 \\
\hline $\mathrm{F}$ & 45.1 & 57.7 & 46.7 & 60.0 & 59.1 & 48.0 & 58.2 & 52.1 & 39.1 & 56.5 & 39.5 & 58.9 & 57.7 & 44.9 & 51.1 & 49.1 \\
\hline $\mathrm{Cl}$ & 46.8 & 54.3 & 50.5 & 57.1 & 55.4 & 48.9 & 55.9 & 49.4 & 40.1 & 53.0 & 41.1 & 55.5 & 54.0 & 45.4 & 48.5 & 45.9 \\
\hline $\mathrm{Br}$ & 46.5 & 54.3 & 50.5 & 57.0 & 55.4 & 48.8 & 54.9 & 48.7 & 40.2 & 52.8 & 41.2 & 55.4 & 54.0 & 45.2 & 47.6 & 45.2 \\
\hline $1^{a}$ & 46.7 & 54.3 & 49.6 & 48.8 & & & 53.9 & 47.7 & 41.1 & 53.0 & 42.5 & 45.4 & & & 46.9 & 44.2 \\
\hline $\mathrm{Me}$ & 45.8 & 53.4 & 50.3 & 56.3 & 54.0 & 48.3 & 56.9 & 48.4 & 38.5 & 51.9 & 39.3 & 54.7 & 52.4 & 44.3 & 46.9 & 44.6 \\
\hline $\mathrm{CN}$ & 44.2 & 42.6 & 44.8 & 45.4 & 48.0 & 43.2 & 57.1 & 49.9 & 35.7 & 41.2 & 35.7 & 44.0 & 43.4 & 42.0 & 47.6 & 45.7 \\
\hline
\end{tabular}

a) The $T_{A}$ structure for $X=I$ is of $C_{2}$ symmetry not $D_{2}$, the given "S1B1" value is that of the S1B value for this structure.

Figure S1. HOMO and LUMO of $\left[\mathrm{Cu}\left(2,9-(\mathrm{X})_{2}-\text { phen }\right)_{2}\right]^{+}$complexes computed with ADF at the S0 ground state.

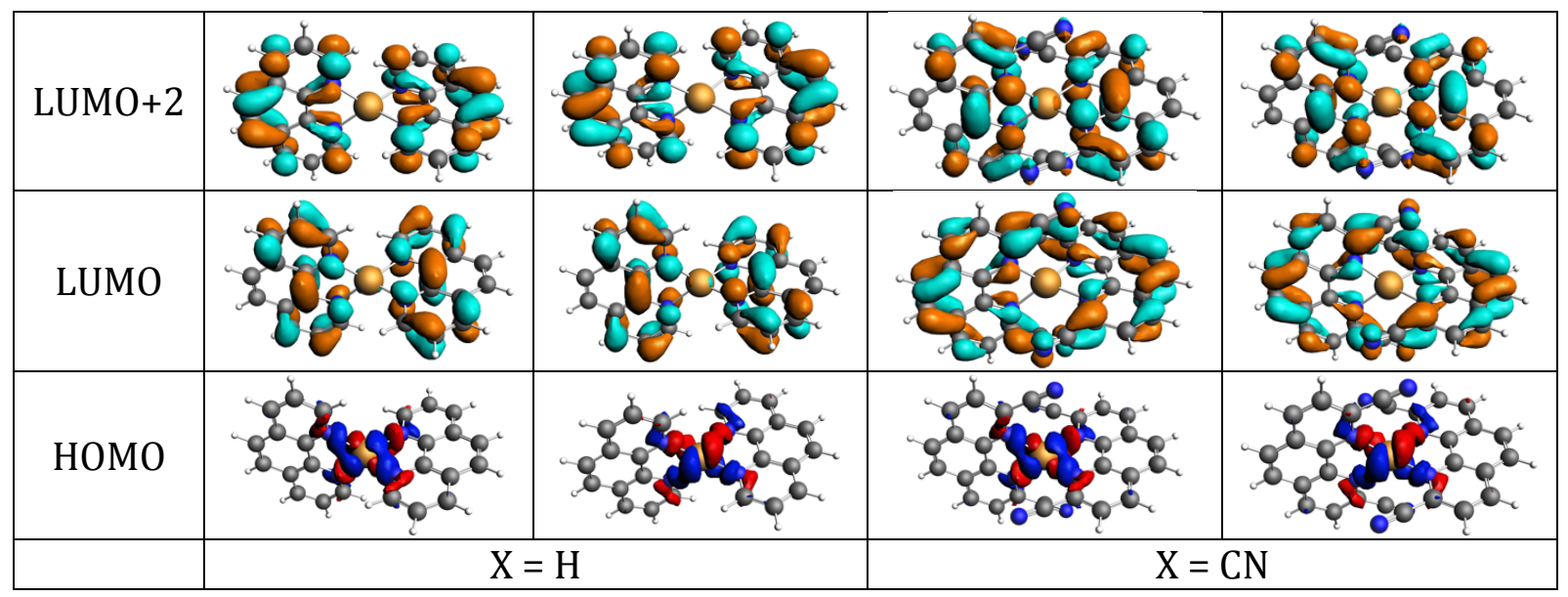




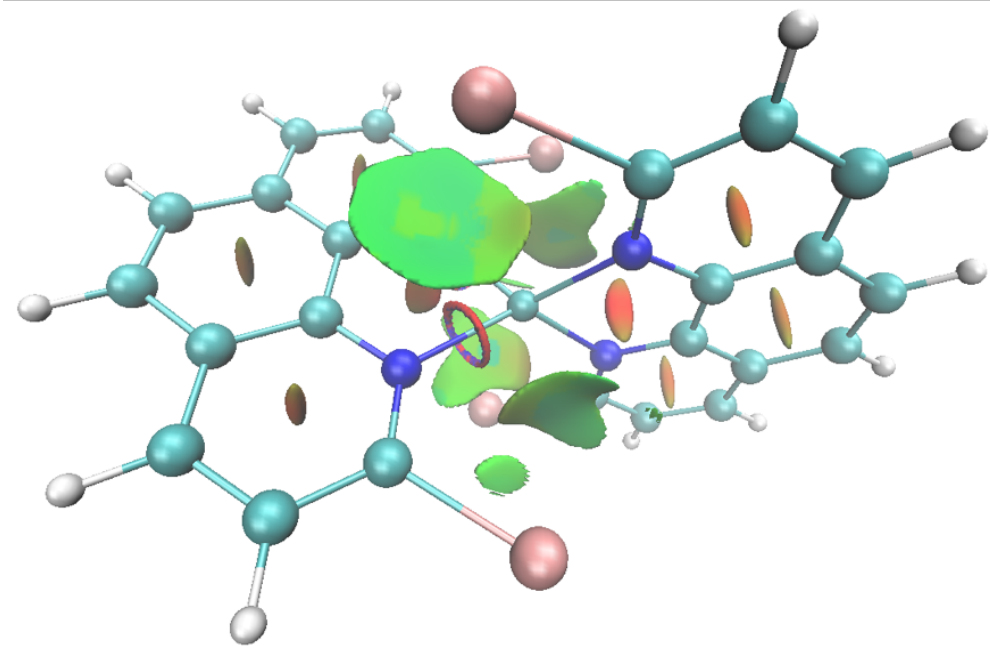

Figure S2. $\mathrm{NCl}$ analysis of the $\mathrm{X}=\mathrm{I}$ complexes in the triplet state at TSB geometry. Green areas stand for Van der Waals forces and red areas for steric congestion. 


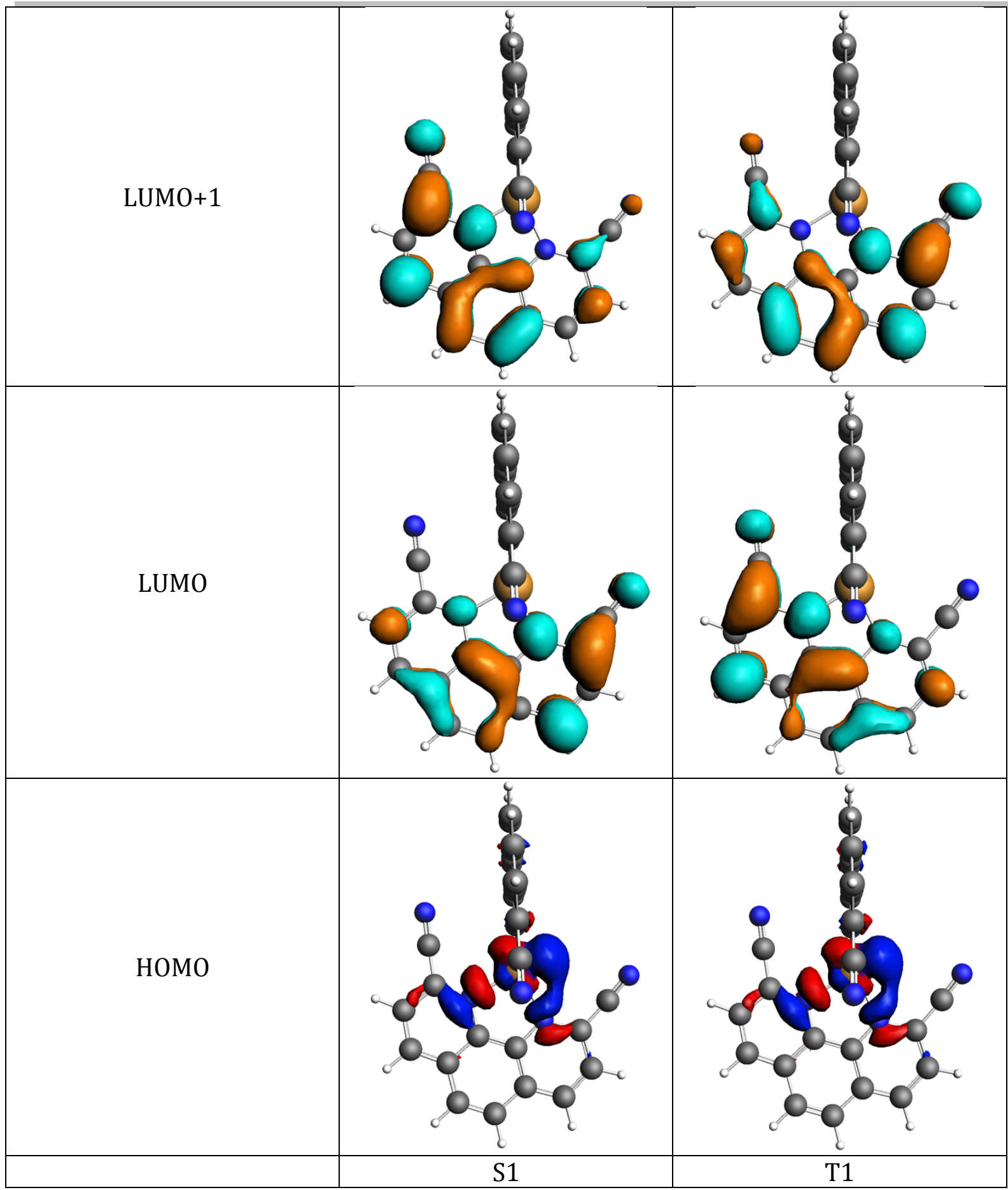

Figure S3: Nature of the HOMO, LUMO and LUMO+1 at the $\mathrm{TS}_{\mathrm{B}}$ geometry for $\mathrm{X}=\mathrm{CN}$ for $\mathrm{S}_{1}$ and $\mathrm{T}_{1}$ states. 


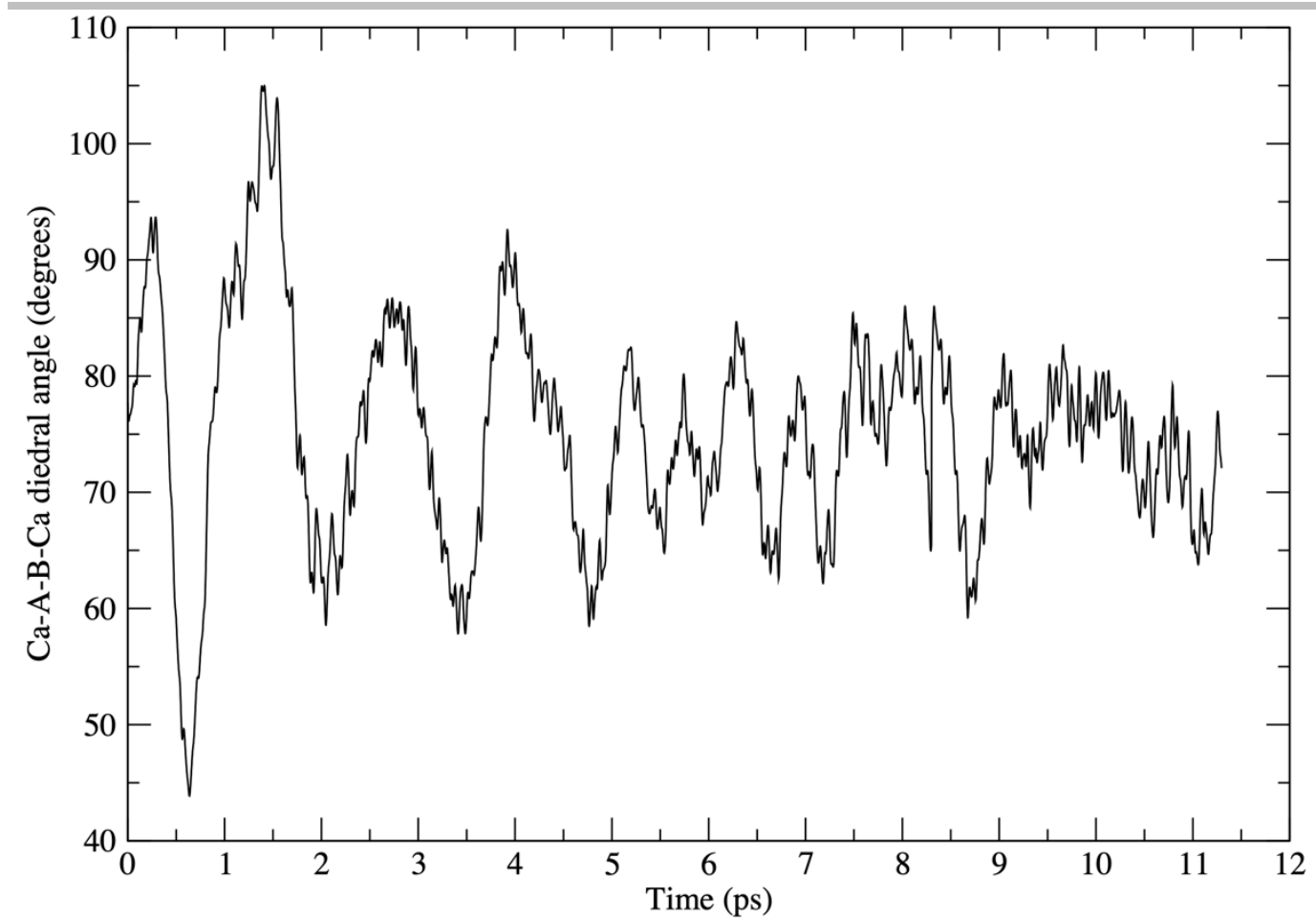

Figure S4. Evolution of the $\mathrm{C} \alpha-\mathrm{A}-\mathrm{B}-\mathrm{C} \alpha$ angle along the $11 \mathrm{ps}$ dynamic. 


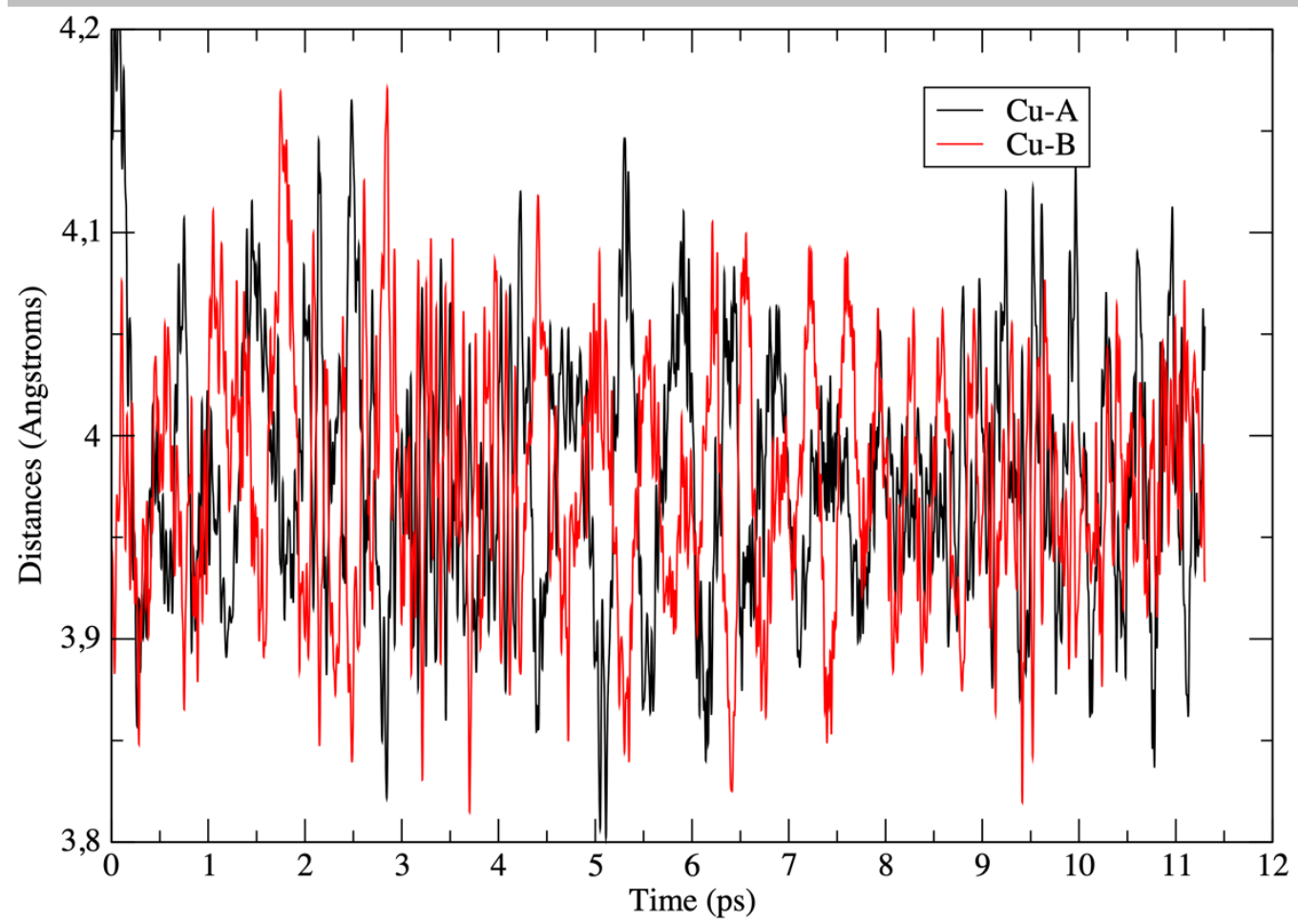

Figure S5. Evolution of the $\mathrm{Cu}-\mathrm{A}$ and $\mathrm{Cu}-\mathrm{B}$ distances along the 11 ps dynamic. 